\title{
Gonadotropin-Resistant Ovary Syndrome
}

National Cancer Institute

\section{Source}

National Cancer Institute. Gonadotropin-Resistant Ovary Syndrome. NCI Thesaurus.

Code C131862.

Ovarian dysfunction due to a defect at the receptor or post receptor level, or due to the presence of antibodies against gonadotropin receptors, resulting in deficient gonadotropin signaling that causes elevated concentrations of follicle stimulating hormone and/or luteinizing hormone. A distinguishing feature is the presence of normal numbers of ova. 